\title{
Exploration and Integration of Ethical Leadership Potential Dimensions and Differential Employee Voice Behaviour - A Strategic Management Perspective
}

\author{
Shathees Baskaran (Corresponding author) \\ Azman Hashim International Business School, Universiti Teknologi Malaysia \\ Level 10, Menara Razak, Jalan Sultan Yahya Petra, 54100 Kuala Lumpur, Malaysia \\ Tel: 60-7561-0120Ｅ-mail: shathees@ibs.utm.my
}

Nomahaza Mahadi

Azman Hashim International Business School, Universiti Teknologi Malaysia Level 10, Menara Razak, Jalan Sultan Yahya Petra, 54100 Kuala Lumpur, Malaysia Tel: 60-321-805-039Ｅ-mail: mahaza@ibs.utm.my

Thanabalan Tangaraja

Azman Hashim International Business School, Universiti Teknologi Malaysia Level 10, Menara Razak, Jalan Sultan Yahya Petra, 54100 Kuala Lumpur, Malaysia Tel: 60-7561-0120Ｅ-mail: thanabalan.t.n@gmail.com

Tai Mee Yuen

Azman Hashim International Business School, Universiti Teknologi Malaysia Level 10, Menara Razak, Jalan Sultan Yahya Petra, 54100 Kuala Lumpur, Malaysia Tel: 60-7561-0120Ｅ-mail: raintai79@gmail.com

Saravin Kumar Binu Kumar

Azman Hashim International Business School, Universiti Teknologi Malaysia 
Level 10, Menara Razak, Jalan Sultan Yahya Petra, 54100 Kuala Lumpur, Malaysia Tel: 60-7561-0120Ｅ-mail: saravin13@gmail.com

Received: May 8, 2018 Accepted: May 25, 2018 Published: June 27, 2018

doi:10.5296/bms.v9i1.13326 URL: https://doi.org/10.5296/bms.v9i1.13326

\begin{abstract}
Business ethics has gained great interest due to rising trend of ethical misconducts around the world. While ethics has its impacts at personal, organizational and societal levels, it is regarded as a moral responsibility of various stakeholders including the leaders and also employees. Therefore, a leader is required to demonstrate an ethical leadership while employees should be given an avenue to voice out their ethical concerns as well. Employees may voice out their ethical concerns in the form of suggestion, problem or opinion while the leader should demonstrate their ethical practices through motive, influences and also moral character. In view of this, a theoretical framework is proposed by incorporating these dimensions supported by relevant literature for conceptualization of the research. Direction for future is also provided to validate and improve predictive value of the research model.

Keywords: Ethical leadership, Employee voice behaviour, Business ethics, Moral character, Suggestion-focused voice behaviour, Problem-focused voice behaviour, Opinion-focused voice behaviour
\end{abstract}




\section{Introduction}

In this fast changing and hypercompetitive business environment, unethical behaviours among leaders have emerged to be an area of concern (De Cremer, van Dick, Tenbrunsel, Pillutla, \& Murnighan, 2011; De Cremer, Mayer, \& Schminke, 2010). This has created a surge of interest in ethical leadership (Avey, Wernsing, \& Palanski, 2012). Morrison (2011) argued that organization's performance and also its survival is associated with an organizational environment which provides employees to communicate issues, concerns and also problems. Baskaran (2018) further clarified that ethics in the organization is also driven by the culture which promotes such behaviours. In spite of this argument, several researchers (e.g. Milliken, Morrison, \& Hewlin, 2003; Perlow \& Williams, 2003; Pinder \& Harlos, 2001) found that many employees are very reluctant to speak up not only to their superiors but also to their peers although they possess information worth sharing for efficient decision making. Employees as insider have the clearest picture about the organization, however due to the risk of speak up, they choose to be silent.

Nevertheless, ethical leader plays a crucial role in breaking the deadlock by influencing the behaviour of employees to voice out their comments and ideas for the purpose of sparking organizational improvement. People are influenced by example and ethical leadership may lead to the decision of employees in justifying whether it is safe to speak up (Detert, \& Burris, 2007). This leads to an important question about role of morality in moulding ethical manners among organizational members (Lennick \& Kiel, 2005). While some research provided evidence of positive association (e.g. Whiting, Podsakoff, \& Pierce, 2009; Vakola and Bourades, 2005; Van Dyne \& LePine, 1998), several other researches has proven the association to be otherwise (e.g. Siebert, Kraimer, \& Crant, 2001) as it is found to create friction and embarrassment (Milliken et al., 2003; LePine \& Van Dyne, 2001). Hence, the literature has witnessed mixed findings in understanding employee voice behavior in the organization.

These contrasting findings for the last two decades indicate that there are still no conclusive evidences in understanding this phenomenon. Although there are continuous debates about employee voice behavior in organization, Burris, Detert, and Romney (2010) clarified that the outcome of this behavior is subject to and usually influenced by the perception hold by the employees and leaders in practicing it in the organization. Therefore, regardless of the association, this area has generated considerable conceptual and empirical interest since there are still quite a lot that are still unknown about this phenomenon (Morrison, 2011) since complications to business and societies continue to exist as a result of unethical behaviours (Baskaran, Yang, Yi, \& Mahadi, 2018).

\section{Literature Review}

\subsection{Ethics in Strategic Management}

Organizations are operating in a competitive environment with various challenges including resource scarcity, intense industry environment, changing consumer needs and evolving 
industry characteristics. Despite of these challenges, effectiveness of an organization decision-making is important (Elbanna \& Child, 2007) with full compliance to business ethics considering that managers act as active ethical subjects to organization moral norm and it is a moral choice of an organization (Ibarra-Colado, Clegg, Rhodes, \& Kornberger, 2006). While unethical conducts are on a rising trend since last four decades (Brenkert, 2010), actions taken by an organization should be morally appropriate for it to be ethical (Jones, Felps, \& Bigley, 2007; Heath, 2006) with a minimum requirement of legal compliance (Hitt \& Collins, 2007).

Generally, the ethical expectations raised by the stakeholders found to influence the strategic management process in organization (Stevens, Steensma, Harrison, \& Cochran, 2005). Hence, ethics must be considered for strategic management to be effective in an organization. Ethic acts as a sense of direction and framework in leading a company to achieve its mission, vision, goals, and objectives. Additionally, ethic can be considered as a guideline to bind the entire organization into a standard management and manage the action and behaviour of the organizational employees. Ethic is subject to the individual on how they manage to express their ethical position in their daily practice (Chan \& Garrick, 2002; Keleman \& Peltonen, 2001). On a broader perspective, issues such as environmental stewardship, community involvement, and employee relations and competitive shortcuts to maintain firm performance are considered as ethical issues (Gunther,2007; Heath, 2006; Windsor,2006).

However, Elms, Brammer, Harris and Phillips (2010) claimed that business ethics research tend to focus more at ethics itself than business. This is evident when the world has witnessed various unethical misconducts which show that the focus has been channelled at profit goals as a measure of a firm's success in spite of being ethical in meeting financial and strategic objectives. This has made the issue of ethics and its influence in strategic management process and decision-making to be continuously debated among researchers (Pajunen, 2006; Kassinis \& Vafeas, 2006).

\subsection{Ethical Leadership and Potential Dimensions}

The role of leadership has evolved from a financial delivery alone to meeting financial and non-financial goals including environmental and social obligations requiring a practice of ethical leadership (Dickson, Smith, Grojean \& Ehrhart, 2001). However, Kalshoven, Hartog and Hoogh (2011) argued that there is no adequate clarity in regards to leaders who choose to influence others through ethical behaviours and those who chooses less ethical behaviours, hence concluded that not much is known about ethical leadership. Past researches on ethical leadership have kept its research focus in understanding consequences rather than antecedents or dimensions. According to Kanungo and Mendonca (1998), a leader when behave ethically tends to manifest three important dimensions: i. leader's motives, ii. the leader's influence strategies, and iii. the leader's character formation. These dimensions depict that an ethical leader employs empowerment instead of control mechanism to influence the followers by operating with an altruistic intent. An ethical leader employing these dimensions is expected to nurture virtues that enable the followers to build upon their inner strength and therefore 
abstaining the employees from engaging in immoralities.

\subsubsection{Leader's Motives for Action}

Kanungo and Mendonca (1998) indicated that ethical leadership is driven by an altruistic intent instead of an egoistic intent. Therefore, whether an employee will be willing to voice out the concerns is dependent on the approach reflected by the leader ( $\mathrm{Li} \mathrm{\&} \mathrm{Wu,} \mathrm{2015).} \mathrm{This}$ is because according to several researchers (e.g. Allen \& Rush, 1998; Ferris, Bhawuk, Fedor, \& Judge, 1995), an intent underpins a leader's motive as it affects leadership effectiveness (Dasborough \& Ashkanasy, 2002). As suggested by the attribution theory, underlying motives dictates an individual's behaviour (Penner, Midili, \& Kegelmeyer, 1997). However, a leader with altruistic intent possess a strong ethical and moral foundation who is also employee-oriented (Bass \& Steidlmeier, 1999). As a result, employees believe a leader's motive reflected through the behaviours and trust that the leader is cultivating an open environment to voice and criticize or challenge the status quo without unexpected consequences although they are inaccurate (Ferris et al., 1995).

Therefore, a leader's motive can create an orientation towards a collective goal allowing the employees to invoke intellectual simulation and voice out concerns without fear of punishments (Li \& Wu, 2015). Conversely, a dysfunctional behaviour among leaders create low morale among followers and making the followers weak and irresponsible and creates a fear of the consequences of wrong ideas (Pinder \& Harlos, 2001). Although moral altruism is universally accepted as a motive for effective leadership, Kanungo and Mendonca (1998) criticized that this issue has been neglected or ignored in discussing ethical issues in leadership. Therefore, employees are expected to openly voice out their ethical concerns when a leader demonstrates the motives for action in fostering and maintaining an ethical organization. On this ground the following propositions are offered:

Preposition 1a: There is significant relationship between leader's motives for action and suggestion-focused voice behaviour.

Preposition 1b: There is significant relationship between leader's motives for action and problem-focused voice behaviour.

Preposition 1c: There is significant relationship between leader's motives for action and opinion-focused voice behaviour.

\subsubsection{Leader’s Influence Strategy}

Research on influence tactics was carried out since last two decades by various researchers (e.g. Yukl, Chavez \& Seifert, 2005; Ansari, 1990; Yukl \& Falbe, 1990). In fostering an ethical business environment, leaders are responsible to guide employee behaviour through the norms and code of conducts (Cyert, 1990) since the leader remains as a primary influence of ethics in organization (Jansen \& Von Glinow, 1985). This is because a leader who sets good example of a business conduct influences employees especially when they get to meet individuals or instances which provides them with such experiences (Kannair, 2007). 
Essentially, past researches (e.g. Yukl, 1989; Kotter, 1985) defined leadership as primarily a process of influence, further supported by Ansari (1990) that it is a first and foremost process of influence. In order to encourage employees to voice out their concerns, a leader may employ several methods. Kanungo and Mendonca (1998) provided some direction into this issue. According to them, a leader may use two approaches to influence their followers: i. transactional modes of influence and ii. transformational modes of influence. The former utilizes position power and rewards to encourage the employees to conform to intended behaviours and desired commitments, while the latter uses empowerment instead of control strategies to bring about the intended change. However, according to Yukl, Chavez, \& Seifert (2005), a leader may use eleven distinct tactics to influence. They are rational persuasion, apprising, inspirational appeals, consultation, collaboration, ingratiation, personal appeals, exchange, coalition tactics, legitimating tactics, and pressure. These tactics may result in commitment, compliance or resistance (Fu \& Yukl, 2000; Yukl et al., 2005). However, employees are found to moderate their commitment, compliance or resistance to a given influence tactics based on their interpretation of the leader's behaviour (Furst \& Cable, 2008; Sparrowe, Soetjipto, \& Kraimer, 2006).

Hence, theoretical developments show that a leader's behaviours such as inspirational motivation (Avolio \& Bass, 2002), personal and organizational identification (Avolio \& Gardner, 2005; Ilies, Morgeson, \& Nahrgang, 2005), and people empowerment (van Dierendonck, 2011) to have influence towards their influence tactics. A leader tends to employ several steps in executing an influence strategy. Among others, it includes elimination of feeling of powerlessness among followers, development of a feeling of competency and expressing confidence about followers' capability in order to either restore or develop the moral atmosphere (Kanungo and Mendonca, 1998). This eventually creates identification and internalization (Mayer, Aquino, Greenbaum, \& Kuenzi, 2012) of ethical attitude among followers through a leader's altruistic intent. Hence, application of an appropriate influence strategy is envisaged to enable employee voice behaviour in the organization. Based on these arguments, the following propositions are proposed:

Preposition 2a: There is significant relationship between leader's influence strategy and suggestion-focused voice behaviour.

Preposition 2b: There is significant relationship between leader's influence strategy and problem-focused voice behaviour.

Preposition 2c: There is significant relationship between leader's influence strategy and opinion-focused voice behaviour.

\subsubsection{Leader’s Moral Character Formation}

A fundamental question in formation of ethical environment in an organization will be what kind of preparation a leader undertakes to ensure compliance towards ethical imperatives arising from challenging environmental demands. According to Palmer (2009), a moral leadership is essential in ensuring organization success. This claim corresponds to Bandura 
(1986)'s social learning perspective where its conceptualization requires a leader to act as a moral role model, manage morality and treat people in a fair manner. An ethical leader will realize that it begins from himself/herself through a moral character formation (Kanungo and Mendonca, 1998). This requires development of an inner strength to behave ethically and morally. Sockol (2009) posited that a moral identity can be observed through an individual's character perspective and social-cognition perspective. Viewing it specifically from an individual's character perspective, Avey, Wernsing and Palanski (2012) explained that concept of ethics has been used in the ancient time to develop an individual's character. Therefore, an individual's focus towards morality inspires moral action (Hardy \& Carlo, 2005) through individual moral cognition (Hannah, Avolio \& May, 2011) consistent with Model of Moral Identity advocated by Blasi (1983).

A focus towards a moral character formation requires that a leader practices highest level of integrity as it serves as the foundation for ethical leadership (Poff, 2010). Demonstration of ethical leadership by leaders influences the employees when these leaders (and their characters) are seen as role models (Hannah, Woolfolk, \& Lord, 2009). This has been proven in implicit theory of morality which assumes that morality tend to influence individuals thence conform to prescribed duties and obligations (Chiu, Hong, \& Dweck, 1997). A leader with moral competence is found to have strong association with employees' behavioural outcomes (Kim \& Kim, 2013) although its consequences are still unclear (Kim \& Kim, 2013; Lennick \& Kiel, 2005). Therefore, moral character formation by leader expected to provide an avenue for employees to be confident in voicing out their ethical concerns. Nevertheless, according to Zhu, He, Treviro, Chao and Wang (2015), the influence of morality beliefs has not been considered in understanding the employees' reaction toward ethical leadership. In view of this, the following propositions are suggested for the research: (e.g. Yukl, Chavez \& Seifert, 2005; Ansari, 1990; Yukl \& Falbe, 1990). In fostering an ethical:

Preposition 3a: There is significant relationship between leader's moral character formation and suggestion-focused voice behaviour.

Preposition 3b: There is significant relationship between leader's moral character formation and problem-focused voice behaviour.

Preposition 3c: There is significant relationship between leader's moral character formation and opinion-focused voice behaviour.

\subsection{Ethical Leadership and Employee Voice Behaviour}

According to Brown, Trevino and Harrison (2005), an ethical leader provides the followers with voice and allow them to report concerns and problem to the management. Mayer, Kuenzi, Greenbaum, Bardes, and Salvador (2009) found that ethical leadership has a distinct domain of extra-role behaviour in leading group level behaviour. Leader who behave ethically has a constructive power of solving problem and point to others idea which would benefit the work unit functioning. According to ethical leadership theory as mentioned by Brown, Trevino and Harrison (2005), ethical leaders "provide followers with voice". 
Morrison (2011) suggested a more nuanced conceptualization of employee voice behaviour by classifying it into three types: i. suggestion-focused voice, problem-focused voice, and opinion-focused voice. According to Morrison, suggestion-focused voice focuses at voices that communicates suggestion with an expectation of realizing new possibilities by challenging status quo of the organization. On the other hand, problem-focused voice will involve "an employee's expression of concern about work practices, incidents, or behaviours that he or she regards as harmful, or potentially harmful, to the organization” (p. 398). The third type, opinion-focused voice, similar to Kassing's (2002) notion of dissent is aimed at "communicating points of view on work-related issues that differ from those held by others" (p. 398), which has been discussed previously by several researchers (e.g. Tangirala \& Ramanujam, 2008; Premeaux \& Bedeian, 2003; Milliken et al., 2003).

Ethical leader who point out the unethical organizational behaviour and convey high moral standard has stronger persuasive power to subordinate. In the aspect of social learning, leader who actively build fair work environment would become role model for people to emulate (Brown et al., 2005). The social learning theory developed by Bandura (1977) stated that individual learning from others by observing, imitating, and modelling. This in line with the statement that subordinate will perform according to the action and behaviour of their leader. Moreover, Miller and Dollard (1941) expressed that observer will be motivated by role model which holding the desired behaviour and perform responses based on the model. Consequently, ethical leaders have the power to encourage their subordinates to speak up opinions and ideas in relation to work context. Van Dyne and LePine (1998) expressed that employee voice behaviour is not only consist of expressing the inappropriate or unethical behaviour in the work environment but also share out practical ideas for the improvement of the organization. In support of this linkage, Walumbwa \& Schaubroeck (2009) found ethical leader has a significant effect to subordinate in reporting problems to management. On this basis, ethical leadership can be considered as positively related to employee voice behaviour. On this ground the following prepositions were formulated:

Preposition 4: There is significant relationship between ethical leadership and employee voice behaviour.

Preposition 4a: There is significant relationship between ethical leadership and suggestion-focused voice behaviour.

Preposition 4b: There is significant relationship between ethical leadership and problem-focused voice behaviour.

Preposition 4c: There is significant relationship ethical leadership and opinion-focused voice behaviour.

\subsection{Conceptual Framework}

Social learning perspective of Bandura (1986) conveys that ethical leadership involves demonstration of personal actions and interpersonal relationships in ethical conducts apart 
from promoting the same to the followers through a two-way communication and reinforcement. In light of this perspective, Freeman (2010) has made a connection between strategic management and business ethics orientation in an explicit way through incorporation of actors, dynamics and trends that has an impact on business. Actors consist of employees who are actually intentionally speak up by sharing constructive opinions in view of work-related issues with an objective of avoiding crisis, hence improving organizational performance (Liang, Farh, \& Farh, 2012; Venkataramani \& Tangirala, 2010).

According to Suchanek, Kasneci and Weikum (2007), ethics has been dealing with two important dimensions. They are justification and implementation discussing about why and how morality becomes important. Most of the normative theories and frameworks have been devoting time to understand the justification and has neglected the implementation aspect (Suchanek et al., 2007). Interaction ethics occurs when there are conflicts on potential and actual interactions among actors with differing goals and more prevalent in an environment where these actors are given freedom to act in different ways. Nevertheless, as cited by Castellazzi (2015), Homann (2000) argued that there are still behavioural interdependencies since the possibility to make decision in isolation is very rare. This is related to a prisoner's dilemma of game theory observed from an ethical perspective which addresses actors' relationships and also robustness of interventions (Verbeek \& Morris, 2010). As explained by the theory, it does not consider potential or actual behaviour but the outcome is rather controlled by conditions of actions in a given situation. Therefore, it is important for a leader to be a moral exemplar, for it to be emulated by the followers (Mayer, Aquino, Greenbaum, \& Kuenzi, 2012; Walumbwa \& Schaubroeck, 2009) through reward and sanctions for displaying ethical behaviours (Mayer et al., 2012; Brown \& Trevino, 2006). In this vein, the following conceptual framework proposed for this research: 


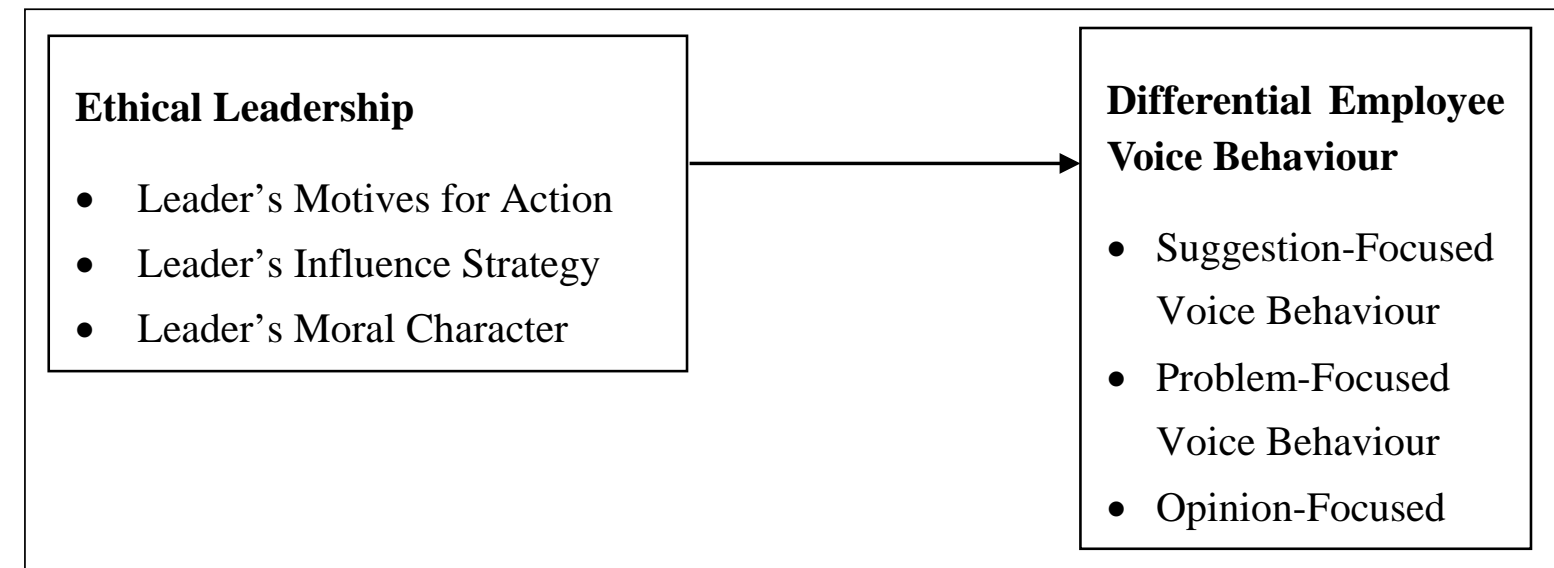

Figure 1. Conceptual Framework

\section{Further Research Directions}

One of the major challenges for global community is ethical leadership (Bello, 2012) as it creates adverse effects (Toor \& Ofori, 2009). This can be attributed to the neglect of leadership morality element in leadership studies (Sendjaya, 2005). However, a leader is surrounded by an environment where a decision is to be made with an ethical risk (Thiel, Bagdasarov, Harkrider, Johnson, \& Mumford, 2012). Hence, a leader is required to create an organizational atmosphere where employees are allowed to voice out their concerns when a decision is being made or while observing immoral activities. Therefore, moral leadership requires the leader to be ethical and at the same time to inspire followers to behave similarly (Rhode, 2006) as well as the challenge unethical events indicating that a leader needs both technical competencies and moral capacities (Ciulla, 1995) to be ethical. However, it should not be done through illegitimate sources of influence because such influences are immoral too (Blackaby and Blackaby, 2001).

This article suffers obvious limitation of lacking empirical investigation. However, it does provide a theoretical rationale in order to contextualize this study for the argument that both leaders and employees play an essential role in cultivating an ethical climate in the organization. Perhaps the most important direction for future research is to validate the proposed theoretical framework through an empirical investigation. In undertaking the empirical investigation, more specific underlying facets which mediates or moderates an ethical environment in the organization can be considered. While there are continuous debates that very little is known about antecedents of ethical leadership, (Kalshoven, Hartog and Hoogh, 2011), inclusion of potential antecedents to the proposed theoretical model will also improve predictive value of the proposed model in understanding ethical leadership phenomenon in organization. 


\section{Conclusion}

To conclude, this study provided a theoretical foundation to understand ethical leadership in respect to employee voice behavior. This theoretical discussion established an extension of employee voice behavior into more specific dimensions namely suggestion-focused voice behaviour, problem-focused voice behaviour, and opinion-focused voice behavior based on conceptual discussion by Morrison (2011). In addition, this article also extended ethical leadership domain by employing dimensions proposed by Kanungo and Mendonca (1998). It is envisaged that proposed conceptual framework will extend the current research domain in the study of ethical leadership. While ethical misconducts can be harmful at personal, organizational and societal levels, a two-way interaction of ethical behaviours of leaders and different voice behavior of employees may offer theoretical contributions and practical implications to the growing concern of ethical issues in the organization.

\section{References}

Allen, T. D., \& Rush, M. C. (1998). The effects of organizational citizenship behavior on performance judgments: a field study and a laboratory experiment. Journal of Applied Psychology, 83(2), 247-260. https://doi.org/10.1037//0021-9010.83.2.247

Ansari, M. A. (1990). Managing People at Work: Leadership styles and Influence Strategies. New Delhi: Sage Publications.

Avey, J., Wernsing, T., \& Palanski, M. (2012). Exploring the process of ethical leadership: The mediating role of employee voice and psychological ownership. Journal of Business Ethics, 107(1), 21-34. https://doi.org/10.1007/s10551-012-1298-2

Avolio, B. J., \& Bass, B. M. (2002). Developing potential across a full range of leadership: Cases on transactional and transformational leadership. Mahwah, New Jersey: Lawrence Erlbaum Associates.

Avolio, B. J., \& Gardner, W. L. (2005). Authentic leadership development: Getting to the root of positive forms of leadership. The Leadership Quarterly, 16(3), 315-338. https://doi.org/10.1016/j.leaqua.2005.03.001

Bandura, A. (1977). Social learning theory. NY: General Learning Press.

Bandura, A. (1986). Social foundations of thought and action: A social cognitive theory. Englewood Cliff, N. J.: Prentice-Hall.

Baskaran, S. (2018). Mediation Effect of Knowledge Management Enablers on the Relationship between Organizational Characteristics and Entrepreneurial Orientation. Gadjah Mada International Journal of Business, 20(1), 1-32. https://doi.org/10.22146/gamaijb.23323

Baskaran, S., Yang, L. R., Yi, L. X., \& Mahadi, N. (2018). Ethically Challenged Strategic Management: Conceptualizing Personality, Love for Money and Unmet Goals. International Journal of Academic Research in Business and Social Sciences, 8(4), 293-311. 
https://doi.org/10.6007/IJARBSS/v8-i4/4015

Bass, B. M., \& Steidlmeier, P. (1999). Ethics, character, and authentic transformational leadership behavior. The Leadership Quarterly, 10(2), 181-217. https://doi.org/10.1016/s1048-9843(99)00016-8

Bello, S. M. (2012). Impact of ethical leadership on employee job performance. International Journal of Business \& Social Science, 3(11), 228-236.

Blackaby. H., \& Blackaby, R. (2001). Spiritual leadership: Moving people on to God's agenda. B\&H Publishing.

Blasi, A. (1983). Moral cognition and moral action: A theoretical perspective. Developmental Review, 3(2), 178-210. https://doi.org/10.1016/0273-2297(83)90029-1

Brenkert, G. G. (2010). The limits and prospects of business ethics. Business Ethics Quarterly, 20(4), 703-709. https://doi.org/10.5840/beq201020444

Brown, M. E, Trevino, L. K, \& Harrison, D. A. (2005). Ethical leadership: A social learning perspective for construct development and testing. Organizational Behavior and Human Decision Processes, 97(2), 117-134. https://doi.org/10.1016/j.obhdp.2005.03.002

Brown, M. E. \& Trevino, L. K. (2006). Ethical Leadership: A Review and Future Directions. Leadership Quarterly, 17(6), 595-616. https://doi.org/10.1016/j.leaqua.2006.10.004

Burris, E.R., Detert, J.R., \& Romney, A. (2010). Speaking up versus being heard: The dimensions of disagreement around and outcomes of employee voice. Working paper, University of Texas.

Castellazzi, S. (2016). Employability and access to training: A contribution to the implementation of corporate responsibility in the labor market. Wiesbaden: Springer VS.

Chan, A. \& Garrick, J. (2002). Organization Theory in Turbulent Times: The Traces of Foucault's Ethics. Organization, 9(4), 683-701. https://doi.org/10.1177/135050840294009

Chiu, C.Y., Hong, Y., \& Dweck, C. S. (1997). Lay dispositionism and implicit theories of personality. Journal of Personality and Social Psychology, 73(1), 19-30. https://doi.org/10.1037//0022-3514.73.1.19

Ciulla, J. B. (1995). Leadership ethics: mapping the territory. Business Ethics Quarterly, 5(1), 5-28. https://doi.org/10.2307/3857269

Cyert, R. M. (1990). Defining leadership and explicating the process. Nonprofit Management \& Leadership, 1(1), 29-38. https://doi.org/10.1002/nml.4130010105

Dasborough, M. T., \& Ashkanasy, N. M. (2002). Emotion and attribution of intentionality in leader-member relationships. The Leadership Quarterly, 13(5), 615-634. https://doi.org/10.1016/s1048-9843(02)00147-9 
De Cremer, D., Mayer, D., \& Schminke, M. (2010). Guest editors' introduction. On understanding ethical behavior and decision making: A behavioral ethics approach. Business Ethics Quarterly, 20(1), 1-6. https://doi.org/10.5840/beq20102012

De Cremer, D., van Dick, R., Tenbrunsel, A., Pillutla, M., \& Murnighan, J. (2011). Understanding ethical behavior and decision making in management: A behavioural business ethics approach. British Journal of Management, 22, S1-S4. https://doi.org/10.1111/j.1467-8551.2010.00733.x

Detert, J.R., \& Burris, E. R. (2007). Leadership behavior and employee voice: Is the door really open? Academy of Management Journal, 50(4), 869-884. https://doi.org/10.5465/amj.2007.26279183

Dickson, M. W., Smith, D. B., Grojean, M. W., \& Ehrhart, M. (2001). An Organizational Climate Regarding Ethics: The Outcome of Leader Values and the Practices that Reflect $\begin{array}{llll}\text { Them. Leadership } \quad \text { Quarterly, 12(2), } & \text { 197-217. }\end{array}$ https://doi.org/10.1016/s1048-9843(01)00069-8

Elbanna, S., \& Child, J. (2007). Influences on strategic decision effectiveness: Development and test of an integrative model. Strategic Management Journal, 28(4), 431-453. https://doi.org/10.1002/smj.597

Elms, H., Brammer, S., Harris, J.D., \& Phillips, R.A. (2010). New Directions in Strategic Management and Business Ethics. Business Ethics Quarterly, 20(3), 401-425. https://doi.org/10.5840/beq201020328

Ferris, G. R., Bhawuk, D. P., Fedor, D. F., \& Judge, T. A. (1995). Organizational politics and citizenship: Attributions of intentionality and construct definition. In M. J. Martinko, Attribution theory: An organizational perspective. Delray Beach, FL: St. Lucie Press.

Freeman, R. E. (2010). Strategic Management: A Stakeholder Approach. Boston: Pitman.

Fu, P. P., \& Yukl, G. (2000). Perceived effectiveness of influence tactics in the united states and china. The Leadership Quarterly, 11(2), 251-266. https://doi.org/10.1016/s1048-9843(00)00039-4

Furst, S. A., \& Cable, D. M. (2008). Employee resistance to organizational change: Managerial influence tactics and leader-member exchange. Journal of Applied Psychology, 93(2), 453-462. https://doi.org/10.1037/0021-9010.93.2.453

Gunther, M. (2007). Green is good. Fortune, 155(6), 42-50. https://doi.org/10.7551/mitpress/9780262035408.003.0011

Hannah, S. T., Avolio, B. J., \& May, D. R. (2011). Moral maturation and moral conation: A capacity approach to explaining moral thought and action. Academy of Management Review, 36(4), 663-685. https://doi.org/10.5465/amr.2011.65554674

Hannah, S. T., Woolfolk, R. L., \& Lord, R. G. (2009). Leader self-structure: A framework for 
positive leadership. Journal of Organizational Behavior, 30(2), 269-290. https://doi.org/10.1002/job.586

Hardy, S. A., \& Carlo, G. (2011), Moral identity: What is it, how does it develop, and is it linked to moral action? Child Development Perspectives, 5(3), 212-218. https://doi.org/10.1111/j.1750-8606.2011.00189.x

Heath, J. (2006). Business ethics without stakeholders. Business Ethics Quarterly, 16(4), 533-557. https://doi.org/10.5840/beq200616448

Hitt, M. A., \& Collins, J. D. (2007). Business ethics, strategic decision making, and firm $\begin{array}{llll}\text { performance. } \quad \text { Business } & \text { Horizons, } & \text { 353-357. }\end{array}$ https://doi.org/10.1016/j.bushor.2007.04.004

Ibarra-Colado, E., Clegg, S. R., Rhodes, C., \& Kornberger, M. (2006). The ethics of managerial subjectivity. Journal of Business Ethics, 64(1), 45-55. https://doi.org/10.1007/s10551-005-3325-z

Ilies, R., Morgeson, F. P., \& Nahrgang, J. D. (2005). Authentic leadership and eudamonic well-being: Understanding leader-follower outcomes. Leadership Quarterly, 163), 373-394. https://doi.org/10.1016/j.leaqua.2005.03.002

Jansen, E., \& Von Glinow, M. A. (1985). Ethical ambivalence and organizational reward systems. Academy of Management Review, 10(4), 814-822. https://doi.org/10.2307/258049

Jones, T. M., Felps, W., \& Bigley, G. A. (2007). Ethical theory and stakeholder-related decisions: The role of stakeholder culture. Academy of Management Review, 32(1), 137-155. https://doi.org/10.5465/amr.2007.23463924

Kalshoven, K., Hartog, D. D., \& Hoogh, A. H. (2011). Ethical Leader Behavior and Big Five Factors of Personality. Journal of Business Ethics, 100(2), 349-366. https://doi.org/10.1007/s10551-010-0685-9

Kannair, J. (2007). The Ethical Mind. Harvard Business Review, 85(3), 51-56.

Kanungo, R. N., \& Mendonca, M. (1998). Ethical Leadership in Three Dimensions. Journal of Human Values, 4(2), 133-148. https://doi.org/10.1177/097168589800400202

Kassing, J. W. (2002). Speaking up: Identifying employees' upward dissent strategies. Management Communication $\quad$ Quarterly, 187-209. https://doi.org/10.1177/089331802237234

Kassinis, G., \& Vafeas, N. (2006). Stakeholder pressures and environmental performance. Academy of Management Journal, 49(1), 145-159. https://doi.org/10.5465/amj.2006.20785799

Kelemen, M. P. \& Peltonen, T. (2001). Ethics, morality and the subject: The contribution of Zygmunt Bauman and Michel Foucault to 'postmodern' business ethics. Scandinavian 
Journal of Management, 17(2), 151-166. https://doi.org/10.1016/s0956-5221(99)00038-X

Kim, T. Y., \& Kim, M. (2013). Leaders' moral competence and employee outcomes: The effects of psychological empowerment and person-supervisor fit. Journal of Business Ethics, 112(1), 155-166. https://doi.org/10.1007/s10551-012-1238-1

Kotter, J. P. (1985). Power and Influence. New York: Free Press.

Lennick, D., \& Kiel, F. (2005). Moral Intelligence: Enhancing Business Performance and Leadership Success. New Jersey: Wharton School Publishing.

LePine, J. A., \& Van Dyne, L. (2001). Voice and cooperative behavior as contrasting forms of contextual performance: Evidence of differential relationships with big five personality characteristics and cognitive ability. Journal of Applied Psychology, 86(2), 326-336. https://doi.org/10.1037//0021-9010.86.2.326

Li, C., \& Wu, K. (2015). Investigation of Motive Between Transformational Leadership and Pro-Social Voice: An Empirical Study in China. International Journal of Leadership Studies, 9(1), 115-130. https://doi.org/10.1037/e518392013-680

Liang, J., Farh, C. I. C. \& Farh, J. L. (2012). Psychological Antecedents of Promotive and Prohibitive Voice: A Two-Wave Examination. Academy Management, 55(1), 71-92. https://doi.org/10.5465/amj.2010.0176

Mayer, D. M., Aquino, K., Greenbaum, R. L., \& Kuenzi, M. (2012). Who displays ethical leadership, and why does it matter? An examination of antecedents and consequences of ethical leadership. Academy of Management Journal, 55(1), 151-171. https://doi.org/10.5465/amj.2008.0276

Mayer, D. M., Kuenzi, M., Greenbaum, R., Bardes, M., \& Salvador, R. (2009). How low does ethical leadership flow? Test of a trickle-down model. Organizational Behavior and Human Decision Processes, 108(1), 1-13. https://doi.org/10.1016/j.obhdp.2008.04.002

Miller, N., \& Dollard, E. (1941). Social learning and imitation. New Haven, CT: Yale University Press.

Milliken, F. J., Morrison, E. W., \& Hewlin, P. (2003). An exploratory study of employee silence: Issues that employees don't communicate upward and why. Journal of Management Studies, 40(6), 1453-1476. https://doi.org/10.1111/1467-6486.00387

Morrison, E.W. (2011). Employee Voice Behavior: Integration and Directions for Future Research. The Academy of Management Annals. 5(1), 373-412. https://doi.org/10.1080/19416520.2011.574506

Pajunen, K. (2006). Living in agreement with a contract: The management of moral and viable firm-stakeholder relationships. Journal of Business Ethics, 68(3), 243-258. https://doi.org/10.1007/s10551-006-9013-9 
Palmer, D. (2009). Business leadership: Three levels of ethical analysis. Journal of Business Ethics, 88(3), 525-536. https://doi.org/10.1007/s10551-009-0117-x

Penner, L. A., Midili, A. R., \& Kegelmeyer, J. (1997). Beyond job attitudes: A personality and social psychology perspective on the causes of organizational citizenship behavior. Human Performance, 10(2), 111-131. https://doi.org/10.1207/s15327043hup1002_4

Perlow, L., \& Williams, S. (2003). Is silence killing your company? IEEE Engineering Management Review, 31(4), 18-18. https://doi.org/10.1109/emr.2003.24935

Pinder, C. C., \& Harlos, K. P. (2001). Employee silence: Quiescence and acquiescence as responses to perceived injustice. Research in Personnel and Human Resources Management, 20, 331-369. https://doi.org/10.1016/s0742-7301(01)20007-3

Poff, D. C. (2010). Ethical leadership and global citizenship: Considerations for a just and sustainable future. Journal of Business Ethics, 93(S1), 9-14. https://doi.org/10.1007/s10551-010-0623-X

Premeaux, S. F., \& Bedeian, A. G. (2003). Breaking the silence: The moderating effects of self-monitoring in predicting speaking up in the workplace. Journal of Management Studies, 40(6), 1537-1562. https://doi.org/10.1111/1467-6486.00390

Rhode, D. L. (2006). Moral leadership: The theory and practice of power, judgment and policy. California: Jossey-Bass.

Sendjaya, S. (2005). Morality and Leadership: Examining the Ethics of Transformational Leadership. Journal of Academic Ethics, 3(1), 75-86. https://doi.org/10.1007/s10805-005-0868-7

Siebert, S. E., Kraimer, M. L., \& Crant, J. M. (2001). What do proactive people do? A longitudinal model linking proactive personality and career success. Personnel Psychology, 54(4), 845-874. https://doi.org/10.1111/j.1744-6570.2001.tb00234.x

Sockol, J. (2009). Ethical decision making: Un-assuming assumptions about what is special... and what is not? Wharton Research Scholars Journal, 63, 1-48.

Sparrowe, R. T., Soetjipto, B. W., \& Kraimer, M. L. (2006). Do leaders' influence tactics relate to members' helping behaviour? It depends on the quality of the relationship. Academy of Management Journal, 49(6), 1194-1208. https://doi.org/10.5465/amj.2006.23478645

Stevens, J. M., Steensma, H. K., Harrison, D. A., \& Cochran, P. L. (2005). Symbolic or substantive document? The influence of ethics codes on financial executives' decisions. Strategic Management Journal, 26(2), 181-195. https://doi.org/10.1002/smj.440

Suchanek, F. M., Kasneci, G., \& Weikum, G. (2007). Yago: A Core of Semantic Knowledge. In Proceedings of the $16^{\text {th }}$ International Conference on World Wide Web (WWW), 697-706

Tangirala, S., \& Ramanujam, R. (2008). Exploring nonlinearity in employee voice: The 
effects of personal control and organizational identification. Academy of Management Journal, 51(6), 1189-1203. https://doi.org/10.5465/amj.2008.35732719

Thiel, C. E., Bagdasarov, Z., Harkrider, L., Johnson, J., Mumford, M. (2012). Leader ethical decision-making in organizations: Strategies for sense making. Journal of Business Ethics, 107(1), 49-64. https://doi.org/10.1007/s10551-012-1299-1

Toor, S., \& Ofori, G. (2009). Ethical leadership: Examining the relationships with full range leadership model, employee outcomes, and organizational culture. Journal of Business Ethics, 90(4), 533-547. https://doi.org/10.1007/s10551-009-0059-3

Vakola, M., \& Bourades, D. (2005). Antecedents and consequences of organizational silence: An empirical investigation. Employee Relations, 27(5), 441-458. https://doi.org/10.1108/01425450510611997

van Dierendonck, D. (2011). Servant Leadership: A Review and Synthesis. Journal of Management, 37(4), 1228-1261. https://doi.org/10.1177/0149206310380462

Van Dyne, L., \& LePine, J. A. (1998). Helping and voice extra-role behavior: Evidence of construct and predictive validity. Academy of Management Journal, 41(1), 108-119. https://doi.org/10.5465/256902

Venkataramani, V., \& Tangirala, S. (2010). When and why do central employees speak up? An examination of mediating and moderating variables. Journal of Applied Psychology, 95(3), 582-591. https://doi.org/10.1037/a0018315

Walumbwa, F., \& Schaubroeck, J. (2009). Leader personality traits and employee voice behavior: Mediating roles of ethical leadership and work group psychological safety. The Journal of Applied Psychology, 94(5), 1275-1286. https://doi.org/10.1037/a0015848

Whiting, S. W., Podsakoff, P. M., \& Pierce, J. R. (2009). Effects of task performance, helping, voice and organizational loyalty on performance appraisal ratings. Journal of Applied Psychology, 93(1), 125-139. Https://doi.org/10.1037/0021-9010.93.1.125

Windsor, D. (2006). Corporate social responsibilities: Three key approaches. Journal of Management Studies, 43(1), 93-114. https://doi.org/10.1111/j.1467-6486.2006.00584.x

Yukl, G. (1989). Managerial Leadership: A Review of Theory and Research. Journal of Management, 15(2), 251-289. https://doi.org/10.1177/014920638901500207

Yukl, G. A., \& Falbe, C. M. (1990). Influence tactics and objectives in upward, downward and lateral influence attempts. Journal of Applied Psychology, 75(2), 132-140. https://doi.org/10.1037/0021-9010.75.2.132

Yukl, G., Chavez, C., \& Seifert, C. F. (2005). Assessing the construct validity and utility of two new influence tactics. Journal of Organizational Behavior, 26(6), 705-725. https://doi.org/10.1002/job.335 


\section{Macrothink}

Business Management and Strategy ISSN 2157-6068

Zhu, W., He, H., Treviro, L. K., Chao, M. M., \& Wang, W. (2015). Ethical leadership and follower voice and performance: The role of follower identifications and entity morality $\begin{array}{llll}\text { beliefs. The } & \text { Teadership } & \text { Quarterly, }\end{array}$ https://doi.org/10.1016/j.leaqua.2015.01.004

\section{Copyright}

Copyright for this article is retained by the author(s), with first publication rights granted to the journal.

This is an open-access article distributed under the terms and conditions of the Creative Commons Attribution license (http://creativecommons.org/licenses/by/4.0/). 